\title{
Contributions to risk injury evaluation of human skin contact caused by welding technology in mechanical engineering a company
}

\author{
Gheorghe Amza ${ }^{1, *}$, Dan Florin $\mathrm{Niţoi}^{1}$, Valentin Dan Petrescu ${ }^{2}$, Oana Roxana $\mathrm{Chivu}^{1}$, and \\ Zoia Apostolescu ${ }^{1}$ \\ ${ }^{1}$ Politechnica University of Bucharest, Spl. Independentei, 313, sector 6, Bucharest, Romania \\ ${ }^{2}$ Lucian Blaga Universiy of Sibiu, B-dul Victoriei, 10, Sibiu, Romania
}

\begin{abstract}
Assembly by welding is a very important pollutant technological process, mainly of the atmosphere and soil. The formation of gas in welding process is the result of electrodes, fluxes burning, formation of fused bath and welded seam. A large number of human operators feels different adverse effects on health. Most problems appears in respiratory system and include bronchitis, respiratory irritation, fever caused by smoke, changes in lung function, decreased immunity to infection and a possible increase of lung cancer risk. Very little information are available about effects on the organism and skin after exposure to fumes from welding, therefore. In this order, this paper do a risk assessment by skin contact. Starting from the main parameters for the evaluation of a cutaneous risk, it was determined a score of danger, a score of surface and a score of frequency. It results a risk associated with each class with a value $\mathrm{S}_{\text {cut }}=100.000$, that indicates a very high probable risk with immediate proposing corrective measures.
\end{abstract}

\section{Introduction}

The technological process of welding is a sum of technological operations that pollutes the atmosphere and soil. Formation of gas and other chemicals in the welding process is the result of burning electrodes, fluxes, formation and developing the welding bath and welded seam. During the welding process, human operators and the auxiliaries personnel are exposed to smoke and toxic gases, arising from the welding process, which can be hazardous to health. Many acute intoxication due to excessive exposure or short exposure to severe smoke and gases that results from the welding process were studied over time [16]. However, besides general effects such as respiratory irritation, long-term effects were directly attributable to the influence of smoke and toxic gases, for example, chronic effects due to the presence of chromium, nickel and aluminum. A large number of welders feel some adverse health effects. Respiratory problems encountered in full-time working includes bronchitis, respiratory irritation, fever caused by smoke, changes in lung function.

\footnotetext{
* Corresponding author: amza@,camis.pub.ro
} 
All these problems decreased immunity to infection and a possible increase in lung cancer risk.

Less information are available about effects on the body and skin after exposure to fumes from welding.

Welding is an important technological method that produces high-quality metal components joints. Essentially, all metals and alloys can be welded, some easily, others involving special precautions. Next will be presented a brief consideration of the welder working in the main production shop where the process of welding technology is developing.

Within the department, the welder performs the following:

- making cores and molds fittings, needed for the casting of iron;

- cutting feeders, network hardware and reworking cast ingots with oxyacetylene flame;

- reworking by welding of cast and heat-treated parts: removing defects detected by visual inspection, magnetic control, penetrant liquid control or ultrasonic testing, by arcair cleaning, filling the areas excavated by welding in accordance with the procedures specific to each type of material;

- creates various welded constructions according to drawings in accordance with welding shop schedule.

In this activity, elements that generates possible health risk are:

- welding equipment and work environment: oxygen-acetylene mixture, welding generator and power transmission cable; welding torches, pliers and accessories (wire brush, hammer welding, protective equipment);

- parts, parts that debits, manufactured and repeated;

- technical equipment in operating area (particularly the cranes);

- the environment in which it operates: its noxious summing with those occurring during welding operations.

The welder executes specific works (autogenous welding and electrical), according its duties.

- organize work, check the technical equipment used in welding;

- regulates the flow of gas (oxyacetylene welding, gas welding protective environment etc.) or connected to power socket welding transformer;

- complies strictly with the obligations incumbent upon it, under the working procedure and working security ruls that has been trained.

Welding work begines after ensuring the safety conditions of labor. As in any process technology, the main pollutants emitted in the working environment or natural surroundings are chemical substances. Highest risk occurring in these jobs is chemical risk produced by a chemical agent.

\section{Risk assessment by skin contact}

One of the biggest risks to which the welder operator and auxiliary workers are subjected is the cutaneous risk because they come into contact directly or indirectly with a variety of chemicals found in liquids, solids or gaseous [10-12].

The risk assessment derived from direct or indirect manipulation of substances in liquid or solid form (powder) in relation to a dermal exposure is the main objective of this work. Since the process of welding can be classified among dispersive open or closed-open, required parameters for this evaluation are:

- hazard class of the product;

- exposed body surface;

- frequency of the exposure; 
In order to make the risk assessment the skin first scoring threat is determined. The hazard classes are determined based on risk classes. Each class will be associated with a score of danger presented in Table 1 .

Table 1. Hazard score by hazard class

\begin{tabular}{|c|l|}
\hline Hazard class & Hazard score \\
\hline 5 & 10000 \\
\hline 4 & 1000 \\
\hline 3 & 100 \\
\hline 2 & 10 \\
\hline 1 & 0 \\
\hline
\end{tabular}

Very important is the skin surface exposed to contact with the chemical agent. Therefore, a score of the exposed surface is determined (Table 2).

Table 2. Determination of the score of exposed skin surface

\begin{tabular}{|l|c|}
\hline \multicolumn{1}{|c|}{ Exposed skin surface } & Skin surface score \\
\hline One hand & 1 \\
\hline $\begin{array}{l}\text { Two hands } \\
\text { A hand and forearm }\end{array}$ & 2 \\
\hline $\begin{array}{l}\text { Two hands and forearm } \\
\text { A full arm }\end{array}$ & 3 \\
\hline $\begin{array}{l}\text { The contact surface comprises upper limbs and torso and/or } \\
\text { pelvis and/or feet }\end{array}$ & 10 \\
\hline
\end{tabular}

Welder operator performs numerous operations during the work schedule, hourly, daily, monthly or annually, so a exposure frequency score is determined also (Table 3).

Table 3. Determination of the exposure frequency score

\begin{tabular}{|l|c|}
\hline \multicolumn{1}{|c|}{ Exposure frequency } & Frequency score \\
\hline Occasional: $<30 \mathrm{~min} /$ day & 1 \\
\hline Intermittent: $30 \mathrm{~min}-2 \mathrm{~h} /$ day & 2 \\
\hline Frequent: $2-6 \mathrm{~h} /$ day & 5 \\
\hline Permanent: $>6 \mathrm{~h} /$ day & 10 \\
\hline
\end{tabular}

Taking all these hnown elements a cutaneous risk score is determined by a the relationship:

$$
\mathrm{S}_{\text {scut }}=\text { Danger Score x Skin Surface Score x Frequency Score }
$$

In the case presentd in paper, with reference to the welding processes, the following result was obtained:

$$
\mathrm{S}_{\text {scut }}=1000 \times 10 \times 10=100.000
$$

This shows a probably high value of skin risk that implies immediately corrective measures. 


\section{Assessing the risk of fire explosion}

Another permanent risk in welding shop is possible risk of fire - explosion. This should be considered in assessing the overall risk to the exposed welder operator. To characterize the risk of fire- explosion the same scale can be used as that used for inhalation risk characterization presented in Table 4 . Based on the process parameters and simplified scheme risk of fire explosion, a simplified scheme of the risk of fire-explosion is presented in figure 1.

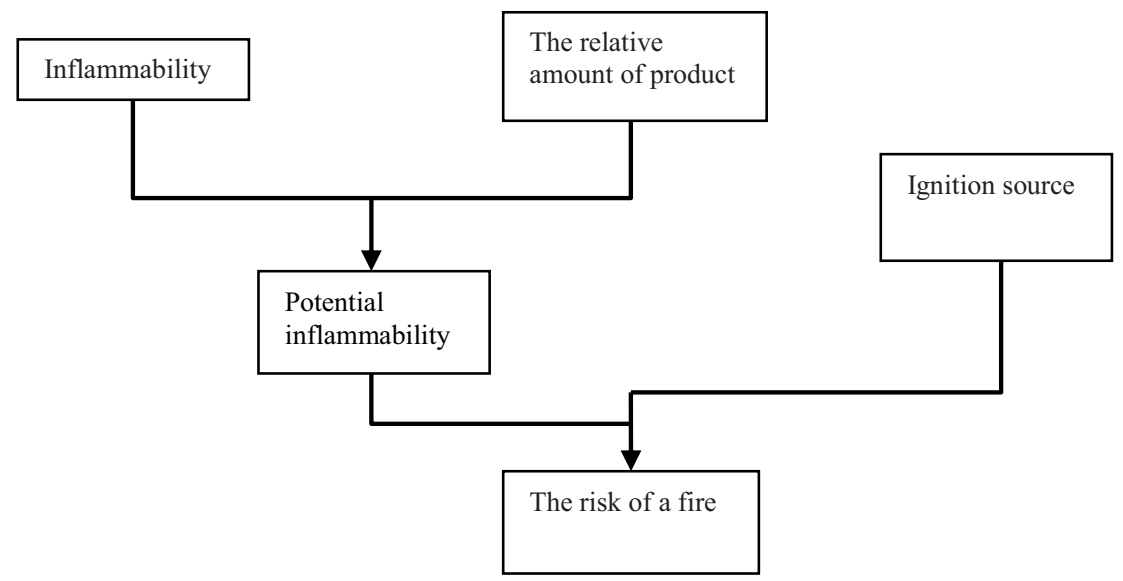

Fig. 1. Simplified scheme of the risk of fire-explosion

For this, paper presents first a classification of potential risk, which aims at classifying chemicals according to their potential flammability and working areas depending on the level of fire risk.

Evaluation data are: the chemical name or trade label, the measured quantity, the ignition source, place of use [13].

Table 4. Class process determination and the associated score

\begin{tabular}{|c|c|c|c|}
\hline Dispersive & Open & $\begin{array}{l}\text { Closed but opened } \\
\text { regularly }\end{array}$ & Closed termanently \\
\hline & $\vec{j}_{1 i}$ & & \\
\hline $\begin{array}{l}\text { Painting gun, manual } \\
\text { emptying of bags, } \\
\text { manual cleaning with } \\
\text { cloths, the use of } \\
\text { portable machines }\end{array}$ & $\begin{array}{lr}\text { Reactors, } & \text { open } \\
\text { mixers, paint brush, } \\
\text { conditioning shops, } \\
\text { surveillance printing } \\
\text { machines }\end{array}$ & $\begin{array}{l}\text { Closed chemical } \\
\text { reactors, sampling, } \\
\text { degreasing machinery } \\
\text { in liquid or vapor } \\
\text { phase }\end{array}$ & Chemical Reactor \\
\hline Class 4 & Class 3 & Class 2 & Class 1 \\
\hline \multicolumn{4}{|l|}{ Procedures score } \\
\hline 1 & 0,5 & 0,05 & 0,001 \\
\hline
\end{tabular}


Evaluation data are: chemical name or trade label, the presented quantity, ignition source, place of use. In the case of conditioned products, flammability hazard class is determined from the information mentioned in the FDS or packaging. When a product has more risk phases, the highest hazard class will be selected. Regarding combustible materials, hazard class is determined by the type of material as shown in table 5 .

Table 5. Determination of the inflammability classes

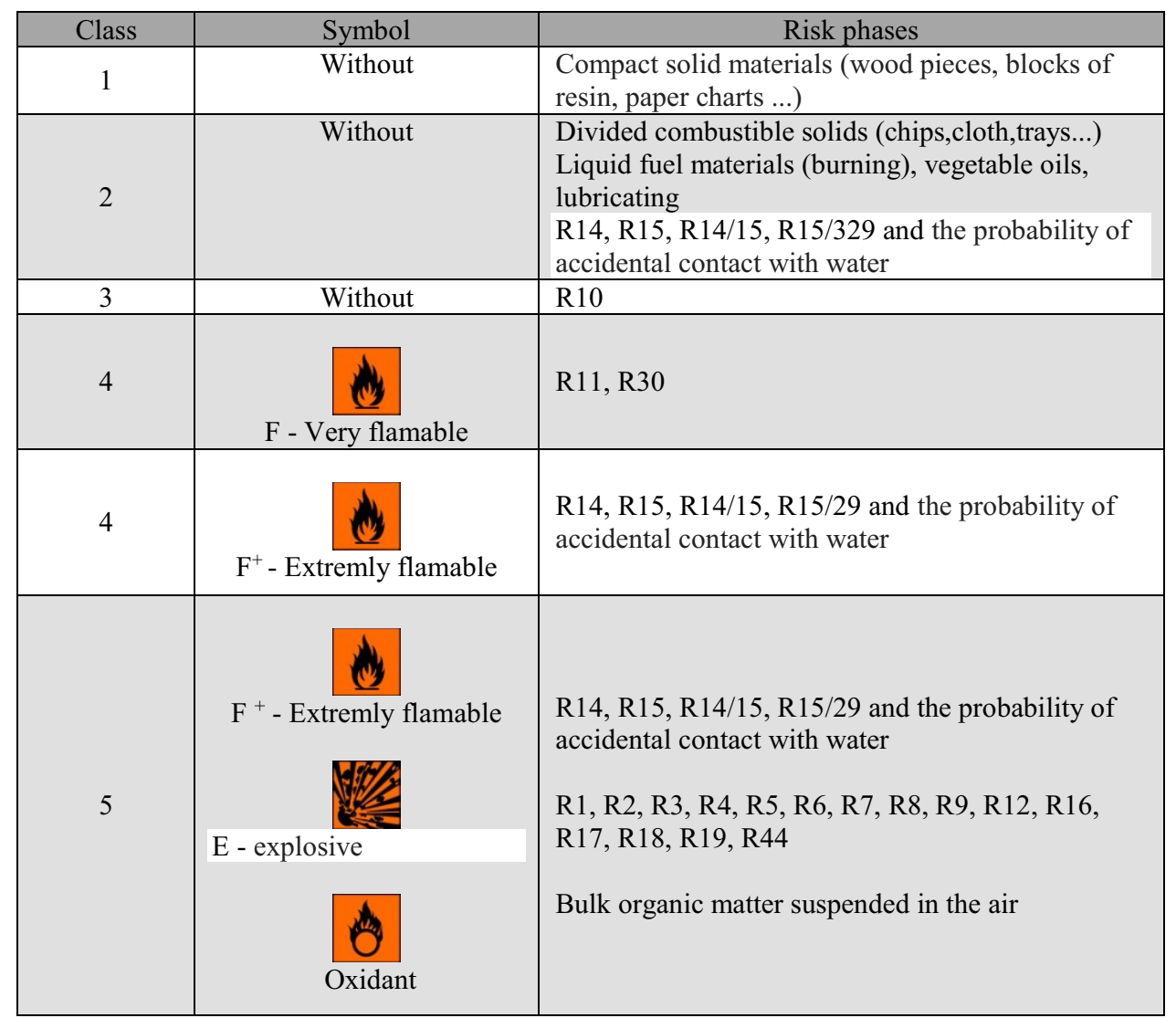

In terms of fire expousure, amount class is a function of the quantities. Determination of classes amount shall be based on the quantity of items found in the greatest amount during inventory (Qmax) and the amount of product $\mathrm{i}(\mathrm{Qi})$. The grid used is the same with methodology used in ESRS (Tab. 6).

Table 6. Defining the quantity thresholds according to the flamability classes

\begin{tabular}{|c|c|}
\hline Flamability classes & Maximal value \\
\hline 5 & $10 \mathrm{~g}$ \\
\hline 4 & $100 \mathrm{~g}$ \\
\hline 3 & $1 \mathrm{~kg}$ \\
\hline 2 & $10 \mathrm{~kg}$ \\
\hline 1 & $100 \mathrm{~kg}$ \\
\hline
\end{tabular}

Depending on the class of product or material, danger thresholds will be applyed for the chemical principal amounts according to Table 6. Products whose quantity is lower this scale are not taken into account when calculating potential flammability. 
Risk analysis of explosion- fire continues taking into account existing sources of ignition, storage, detection and protection (security organization and means of prevention etc).

Using Table 7, the grades of fire ignition will be determined, which in the present case is 5. In the case when for a working place there are several sources of ignition, the highest value of the class will be retained.

Table 7. Determination classes of ignition sources

\begin{tabular}{|c|l|l|}
\hline $\begin{array}{c}\text { Ignition source } \\
\text { class }\left(\mathbf{S}_{\mathbf{a}}\right)\end{array}$ & \multicolumn{1}{|c|}{ Ignition source example } & \multicolumn{1}{c|}{$\begin{array}{c}\text { The frequency of the source of } \\
\text { ignition }\end{array}$} \\
\hline 5 & \multicolumn{1}{|c|}{ Fumes } & Hot flames in equipment or processes \\
\hline \multirow{2}{*}{4} & $\begin{array}{c}\text { The steps of heating equipment for } \\
\text { cleaning, the heat sealing operation, etc, }\end{array}$ & Permanent presence of ignition source \\
\cline { 2 - 4 } & Work in hot spots & Ocasional presence of the process \\
\hline \multirow{2}{*}{3} & $\begin{array}{l}\text { Withdrawal / loading of organic or } \\
\text { flammable products }\end{array}$ & $\begin{array}{l}\text { The presence is related to the } \\
\text { maintenance }\end{array}$ \\
\hline \multirow{2}{*}{2} & Electric incident & $\begin{array}{l}\text { The ignition source is linked to the } \\
\text { emergence of static electricity }\end{array}$ \\
\hline \multirow{2}{*}{1} & Sabotage or natural phenomenon & $\begin{array}{l}\text { The ignition source is caused by a } \\
\text { malfunction, wear or handling error... }\end{array}$ \\
\hline & & $\begin{array}{l}\text { External or accidental source of } \\
\text { natural origin (lightning) }\end{array}$ \\
\hline
\end{tabular}

With the above data the potential flammability classes, denoted by Ip can be determined.Potential flammability results by combining hazard classes and quantity. Potential flammability classes are determined using the grid shown in Table 8, which when analyzed section is 4 .

Table 8. Determination of potential flammability classes

\begin{tabular}{|c|c|c|c|c|c|c|}
\hline $\begin{array}{c}\text { Flammability } \\
\text { classes }\end{array}$ & & & & & & \\
\hline 5 & 3 & 4 & 5 & 5 & 5 & \\
\hline 4 & 3 & 3 & 4 & 4 & 5 & \\
\hline 3 & 2 & 2 & 3 & 3 & 4 & \\
\hline 2 & 1 & 1 & 2 & 2 & 2 & \\
\hline \multirow[t]{2}{*}{1} & 1 & 1 & 1 & 1 & 1 & \\
\hline & 1 & 2 & 3 & 4 & 5 & $\begin{array}{l}\text { Quanti } \\
\text { ty } \\
\text { class }\end{array}$ \\
\hline
\end{tabular}


Starting from potential flammability class Ip of a product used in a location and the presence of ignition sources SA, the risk score potential for starting a fire can be determined. These scores are in addition to prioritize the different entities depending on the level of risk. Score potential risk of starting a fire is determined according to the chart presented in table 9 resulting in the present case the value of 5000 .

Table 9. Determination of potentially risk score of starting a fire

\begin{tabular}{|c|c|c|c|c|c|c|}
\hline $\begin{array}{l}\text { Potential } \\
\text { flammability } \\
\text { class Ip }\end{array}$ & & & & & & \\
\hline 5 & 2000 & 5000 & 10000 & 30000 & 100000 & \\
\hline 4 & 300 & 1000 & 2000 & 5000 & 10000 & \\
\hline 3 & 30 & 100 & 300 & 1000 & 2000 & \\
\hline 2 & 3 & 10 & 30 & 100 & 300 & \\
\hline \multirow[t]{2}{*}{1} & 1 & 1 & 3 & 10 & 30 & \\
\hline & 1 & 2 & 3 & 4 & 5 & $\begin{array}{l}\text { Class ignition } \\
\text { source }\end{array}$ \\
\hline
\end{tabular}

Finally, with all results presented above, the risk characterization of rough fire ignition can be done according to Table 10 .

Because, in the present case, the results obtained is 5.000 important potential fire hazard is present.

Table 10. Characterization of the fire potential risk

\begin{tabular}{|c|c|c|c|c|}
\hline Scor & $\geq 10000$ & $100-10000$ & $10-1000$ & $<10$ \\
\hline $\begin{array}{c}\text { Potentioal risk } \\
\text { characterisation }\end{array}$ & Very important & Important & Moderate & low \\
\hline
\end{tabular}

This risk estimate does not account for the actual conditions of use of the product and the means of protection. Applying this method of grading allows for products and / or workshops to be analyzed first. Situations characterized by values of lead more than 10,000 correspond most likely non-compliant situations (eg presence of an open fire in a work area where highly flammable products are used).

\section{Conclusions}

Analyzing the experimental results can draw the following conclusions:

- production of machine-building enterprises is extremely varied and flexible technological processes are extremely complex and using different materials and technological equipment, highly diverse, technical and economic conditions totally different;

- there are many parameters that influence technological process differently emission of pollutants in the workplace based on physical phenomena, chemical, mechanical, electrical, magnetic and nuclear occurring during the technological process; 
- in the determinations made in the welding shop, in different areas, on the breath level, it was found that the amount of inhalable particulate concentrations, aerosol and fumes from various metals exceeds the CMA Order 1957/1995, in different places and in different measured proportion;

- risk assessment by skin contact was calculated taking into account: product hazard class; expusp body surface and frequency of exposure, resulting in a very probable risk $\left(\mathrm{S}_{\mathrm{cut}}=100,000\right)$ that requires immediate corrective action;

- simplified risk assessment fire explosion was done by going through the steps of ranking potential risk; determining the flammability class; risk score to determine potential for starting a fire (which in the present case is equal to 5000), which means that the potential fire hazard is important.

\section{References}

1. Gh. Amza, V. Aionesie, TQSD, (Bucuresti, 2008)

2. Gh, Amza, TQSD, 157, (Bucuresti, 2008)

3. Gh, Amza, Ecotehnologie, 972 (2007)

4. Gh, Amza, Ecotehnologie si dezvoltare durabila, 1258 (2009)

5. Gh, Amza, Tratat de tehnologia materialelor, 1682 (2002)

6. Gh, Amza, Tehnolgia materialelor, IV (2003)

7. http://reach.anpm.ro/Helpdesk.aspx, Agenţia Europeană pentru Substanțe Chimice (ECHA), pagina dedicată utilizării produselor chimice în condiţii de siguranţă la locul de muncă

8. http://echa.europa.eu/ro/use-chemicals-safely-at-work, Agenţia Europeană pentru Securitate şi Sănătate în Muncă, tema Substanţe periculoase

9. https://osha.europa.eu/ro/topics/ds, Inspecţia Muncii, pagina dedicată IMM-urilor, riscuri profesionale chimice

10. http://www.inspectiamuncii.ro/ssmimm/p1b.html, Afişul Etichetele produselor chimice se schimbă - cum vă afectează

11. H. Kumamoto, J.E. Henley, IEEE Transactions on Reliability, R-27, 242 (1978)

12. E.W. Lawless, M.V. Jones, Risk Evaluation and Management, (Plenum Press, 1986)

13. S. Pece, Risc şi securitate în muncă, 34 (1994) 